УДК 61:621.395.004

DOI: http://dx.doi.org/10.11603/mie.1996-1960.2016.3.6746

\title{
ШЛЯХИ РОЗВИТКУ МОБІЛЬНОї МЕДИЦИНИ
}

\section{О. П. Мінцер}

\author{
Національна медична академія післядипломної освіти імені П. Л. Шупика
}

\begin{abstract}
Розглянуто питання застосування технологій мобільної медицини в практичній охороні здоров'я.
Запропонована класифікація мобільних пристроїв, що вже сьогодні надзвичайно широка та включає щонайменше 15 груп, котрі були нами розбиті на чотири підгрупи. Узагальнено напрями застосування мобільної медицини на тепер. Підкреслено, що клінічна дерматологія являє ідеальну модель для демонстрації ефективності використання М-медицини. Другою моделлю названа офтальмологія.

Зроблено висновки, що мобільні пристрої потребують пильної уваги, перш за все внаслідок їх високої ефективності в умовах обмежених ресурсів; для забезпечення есективного впровадження технологій М-медицини необхідне прискорене розроблення нормативно-правового забезпечення застосування мобільних пристроїв.
\end{abstract}

Ключові слова: мобільна медицина, електронна медицина, смарторони, планшети, телемедицина, класифрікація мобільних пристроїв, нормативно-правове забезпечення застосування мобільних пристроїв.

\section{ПУТИ РАЗВИТИЯ МОБИЛЬНОЙ МЕДИЦИНЫ}

\section{О. П. Минцер}

\author{
Национальная медицинская академия последипломного образования имени П. Л. Шупика
}

Рассмотрены вопросы применения технологий мобильной медицины в практическом здравоохранении.

Цель исследования - анализ реальных перспектив мобильной медицины и ее развития.

Предложена классиорикация мобильных устройств, которая уже сегодня чрезвычайно широка и включает не менее 15 групп, разбитых нами на четыре подгруппы. Выполнен обзор направлений применения мобильной медицины в настоящем времени. Подчеркнуто, что клиническая дерматология представляет собой идеальную модель для демонстрации эффективности использования М-медицины. Второй моделью названа офтальмология.

Сделаны выводы о том, что мобильные устройства требуют пристального внимания, прежде всего, вследствие их высокой эффеективности в условиях ограниченных ресурсов; для обеспечения эффективного внедрения технологий М-медицины нужна ускоренная разработка нормативно-правового обеспечения применения мобильных устройств.

Ключевые слова: мобильная медицина, электронная медицина, смартфоны, планшеты, телемедицина, классиорикация мобильных устройств, нормативно-правовое обеспечение применения мобильных устройств.

\section{WAYS OF MEDICINE MOBILE}

\section{O. P. Mintser}

\section{Shupyk National Medical Academy of Postgraduate Education}

Question of the use of mobile technology in the practice of medicine and public health is considered.

The purpose of research was analysis of the real prospects of m-medicine and its development.

It was proposed the mobile devices classification. It includes, at least, 15 groups. They were divided into four subgroups. It was done a review of the mobile medicine applications in the present time. It was emphasized that clinical dermatology is an ideal model to demonstrate the effectiveness of the use M-medicine. The second model is ophthalmology.

Conclusions. 1. Mobile devices require attention, primarily as a result of their high efficiency in terms of limited resources. 2. To ensure effective implementation of $m$-Medicine technology there is a need for the accelerated development of regulatory support of mobile devices usage.

Key words: mobile medicine, e-medicine, Smart phones, tablets, telemedicine, mobile classification, regulatory and legal framework for the mobile devices use.

(c) О. П. Мінцер 
Вступ. У світовій літературі мобільна медицина відома під назвою mHealth. Це поняття включає використання мобільного зв'язку та пристроїв для надання послуг як пацієнтам, так і лікарям.

Мобільну медицину також відносять до електронної медицини (англ. e-health - e-медицина), що об'єднує цей напрям із використанням електронних інформаційних ресурсів у сфері охорони здоров'я та забезпеченням оперативного доступу медичних працівників і пацієнтів до них [1]. Е-медицина почала набувати розповсюдження у світі з 1999 року [8]. 3 того часу значення терміну постійно змінюється та розширюється: від практик охорони здоров'я з використанням Інтернету до застосування комп'ютерів у медицині $[10,13]$.

Мобільні пристрої можуть допомогти людям управляти власним здоров'ям, сприяти здоровому способу життя, а також отримати доступ до корисної інформації, коли й де їм це необхідно. Одним із найбільш поширених мобільних пристроїв вважаються смартфон і планшет [12].

Неочікуваним наслідком виявилося їх застосування в охороні здоров'я. Цифри статистики свідчать, що якщо в 2004 році у США лише кожен четвертий лікар-практик використовував смартфон у професійних цілях, то через шість років цей показник перевищив 50 \%. Відповідно до оцінок промисловості більше 500 млн. користувачів смартфонів і планшетів по всьому світу в 2015 році використовували програмне забезпечення охорони здоров'я, а до 2018 року 50\% смартфонів і планшетних ПК більш ніж 3,4 млрд. користувачів (відповідно до прогнозних характеристик) будуть завантажені мобільними додатками з проблем охорони здоров'я [33]. Підкреслимо, що до когорти користувачів входять як фахівці в області охорони здоров’я, так і лікарі, провізори та, зазвичай, пацієнти.

Важливо підкреслити, що в розвинених державах всіляко стимулюється розвиток мобільних медичних програм - це покращує медичне обслуговування і забезпечення споживачів і фахівців в області охорони здоров'я цінною інформацією про стан здоров'я [6]. Так, в Сполучених штатах Америки широко відоме агентство FDA ще в 2013 році випустило спеціальне керівництво, в якому підкреслює особливу увагу агентства до мобільних медичних програм, які можуть представляти великий ризик для пацієнтів, якщо вони не використовуються за призначенням або впливають на функціональність чи продуктивність традиційних медичних пристроїв [18]. Широке поширення і використання мобільних технологій відкриває нові та інноваційні шляхи для поліпшення здоров'я і надання медичної допомоги.

Смартфони використовуються також і для підтримки медичної освіти і клінічної практики в консиліумах [27]. За думкою Bruno S. Oliveira, стрімкий прогрес у сфері мобільних технологій може та повинен бути використаний лікарями для самонавчання, роботи з документацією та ведення обліку, а також підвищення ефективності роботи з пацієнтами [21].

Деякі дослідження відзначили успішне використання мобільних телефонів для підтримки телемедицини та дистанційної охорони здоров’я в країнах, які розвиваються [31], з прикладами, включаючи їх використання поза клінічної медичної діагностики [14] та як інформаційну підтримку у важкодоступних для охоплення сільських районів [26].

Однак, поширення смартфонів, планшетів та інших мобільних гаджетів одночасно обумовило надзвичайно важливе питання: як забезпечити відповідальність виробників медичних програм для цих пристроїв в плані контролю їх безпеки і ефективності. Визнається все більша необхідність посиленого захисту спеціалізованих ресурсів е-медицини від кібератак, що вимагає розробки більш надійної інфраструктури в цій області [4].

На цьому тлі в Україні існують лише поодинокі приклади, більшість же лікарів вважають мобільну медицину просто модною іграшкою для молоді. Розвиток М-медицини у нашій країні стримують і інші негативні чинники, такі як брак фінансування галузі охорони здоров'я, низький рівень інформатизації лікувальних установ, недостатнє володіння IT-культурою серед медичних працівників, надмірна консервативність суспільства, нарешті, загальна байдужість людей до свого здоров'я [2]. Тим не менш, за даними компанії «Київстар», на сьогодні існують уже близько 8 млн. смартфонів у мережах мобільних операторів, і їх кількість постійно зростає [5].

Мета роботи: аналіз реальних перспектив мобільної медицини та її розвитку.

Результати та їх обговорення. Класифікація мобільних пристроїв уже сьогодні надзвичайно широка. Вона включає щонайменше 15 груп, що були нами розбиті на чотири підгрупи:

1. Кваліфікуються як медичні пристрої та потребують спеціальної реєстрації та сертифікації. 
2. Не кваліфікуються як медичні пристрої та не потребують спеціальної реєстрації та сертифікації.

3. Підлягають контролю за використанням.

4. Використовуються як аксесуар для регульованого медичного пристрою або перетворюють мобільну платформу в регульованому медичному пристрої.

Гаджети, що використовуються як аксесуар для регульованого медичного пристрою або перетворюють мобільну платформу в регульованому медичному пристрої [23], мабуть, найбільш багаточисельні. Ïx, у свою чергу, розділяють на декілька груп:

- пристрої, що забезпечують електронний доступ до довідкових матеріалів (наприклад, до медичних словників);

- пристрої, що використовуються для навчання практикуючих лікарів (наприклад, медичні флеш-карти);

- пристрої, що призначені для інформаційної допомоги пацієнту (наприклад, містять рекомендації щодо вибору ліків-генериків - таблиця порівнянь);

- пристрої, що призначені для автоматизації загальних офісних операцій в клініках (наприклад, визначення кодів рахунків);

- пристрої, що є універсальними інструментами, не призначеними саме для медичних цілей (наприклад, додаток, який діє як збільшувальне скло);

- мобільні медичні програми.

Пристрої, що об’єднані в другу групу, також суттєво відрізняються один від одного. Можна виділити такі гаджети:

- управління пристроєм або дисплеєм для зберігання, аналізу та передачі даних медичного обстеження конкретного пацієнта (наприклад, віддалений моніторинг даних пацієнта від приліжкового монітору) [15];

- перетворювачі інформації (наприклад, приєднання датчику аналізу рівня глюкози в крові пацієнта на мобільну платформу, що здійснює обробку даних) [26];

- обчислювачі інформації конкретного пацієнта з подальшим аналізом для діагностики або лікування (наприклад, додаток, що обчислює дози випромінювання на основі власних даних пацієнта).

Стосовно приладів третьої (а також частки першої) групи, їх можна об’єднати в такі підгрупи:

- надають інформаційну підтримку, тренуючи або спонукаючи пацієнтів керувати своїм здоров’ ям (наприклад, сприяння правильному диханню, харчуванню);

- організовують або відслідковують власну медичну інформацію щодо здоров’я пацієнта (наприклад, відстежуючи вимірювання артеріального тиску);

- забезпечують доступ до інформації про стан здоров’я або лікування пацієнта (наприклад, інформаційний інструмент використання окремих лікарських засобів (вживання анальгетиків));

- комунікатори для спілкування зі своїми лікарями про можливі зміни медичних умов (забезпечення відеозв’язку між пацієнтом і лікарем);

- виконання простих медичних розрахунків (наприклад, обчислення гармонізованих характеристик (індексів) зріст / маса тіла тощо);

- забезпечують взаємодію з пацієнтом щодо електронних медичних записів, котрі покликані полегшити управління медико-санітарною інформацією пацієнта (персональна історія хвороби).

Можливі ризики для здоров’я пацієнтів можуть представити вироби, що формально не включаються у перелік медичних приборів, але призначені для використання або як аксесуар для регульованого медичного пристрою або перетворення мобільної платформи у регульований медичний аппарат [11, 18]. Підкреслимо, що досить складно забезпечити регулювання пристроїв, які виробляють або змінюють мобільний медичний додаток виключно для своєї професійної практики. Ще більші проблеми можуть виявитися при застосуванні мобільних медичних додатків у наукових дослідженнях, навчанні або аналітичних цілях.

Проте, узагальнимо напрями застосування мобільної медицини на даний час.

Клінічна дерматологія являє ідеальну модель для демонстрації ефективності використання М-медицини. Вона надає діагностичні можливості, моніторинг потенційно злоякісних і хронічних уражень шкіри на підгрунті об’єктивних даних.

Тематичні дослідження показали високу чутливість і специфічність мобільного телефону «teledermoscopу» для оцінювання та моніторингу потенційно злоякісних уражень шкіри [17, 19]. Ефективними виявилися технології використання смартфонів для моніторингу стану ран, зокрема у пластичній хірургії [30], для оцінювання опіків i післяопераційних рубців [25]. У більшості випадків дослідження свідчили, що з мінімальним додатковим навчанням, медичні працівники неспеціалісти 
(лікарі в навчальних закладах, медичні сестри, суміжні медичні працівники) можуть забезпечити виконання простих завдань з отримання та аналізу зображень $[7,16]$. Це визначає значні вигоди в сільських і віддалених районах, де є дистрибутивні проблеми та брак спеціалізованих кадрів.

Другим класичним медичним напрямом застосування М-медицини вважається офтальмологія. Запис відео (чи фотографування) є важливим компонентом для документування хірургічних i клінічних деталей [22]. Крім того, відео мають важливу роль в передаванні навиків, демонстрації нових процедур. Застосування мобільних пристроїв збільшило також потенціал для сприяння своєчасної діагностики та прискорення управління лікуванням захворювань ока в загрозливих умовах. Так, у світовому масштабі рефракція залишається основною причиною всіх порушень зору. Для вирішення цієї проблеми, в рамках виконання програми NETRA (Near Eye Tool for Refractive Assessment) був розроблений оптичний пристрій, пристосований для використання із смартфоном, щоб дозволити виконувати суб'єктивне автоматичне дослідження [32].

Смартфони були також досліджені як доповнення до диспансеризації хворих з офтальмологічною патологією. Продемонстровані комерційно доступні адаптери щілинної лампи, для забезпечення адекватної якості зображення в передній камері ока [20]. 3 огляду на те, що в камерах смартфонів щорічно підвищується якість зображення [28], можна припустити, що в найближчому майбутньому вони зможуть забезпечити високоякісне зображення очного дна для своєчасного направлення пацієнтів у високоспеціалізовану лікарню.

Хоча на згадані спеціальності припадає найбільша частина сьогоднішніх доказів ефективності М-медицини, завдяки своєї універсальності сфера застосування смартфонів розширилася майже в усіх галузях охорони здоров’я [9]. В кардіології ряд додатків було розроблено для контролю клінічно важливих параметрів, зокрема варіабельності серцевого ритму й аритмій [29]; у нейрохірургії запропоновано пристрої, що дозволяють лікарям точно позиціонувати шлуночкові катетери при виконанні комп’ютерної томографії [27].

Незважаючи на зростаючий обсяг літератури з М-медицини, недавні мета-аналізи показали, що на даний час $є$ лише відносно невелика частка застосувань мобільних пристроїв, які забезпечують високу методологічну якість [31]. В інших випадках відсутні об’єктивні клінічні результати, серед досліджень з аналогічними втручаннями виявляється гетерогенна неоднорідність. Крім того, більшість досліджень були проведені в країнах з високим рівнем доходу. Це обмежує ступінь, в якому результати можуть бути контекстуалізованими в умовах обмежених ресурсів, де позиціонується мобільна медицина, щоб забезпечити найбільший вплив.

Якщо проаналізувати урозуміння М-медицини в Україні, то переважно мається на увазі проект, спрямований на розвиток телемедицини шляхом інтеграції передового медичного досвіду та сучасних телекомунікаційних технологій. Основною метою вважається забезпечення доступною високоспеціалізованою медичною допомогою мешканців обласних центрів, а також пацієнтів, які приїжджають на консультацію до обласної лікарні з віддалених населених пунктів.

Загальноприйнятого визначеного поняття «телемедицина» не існує [24]. 3 точки зору Американської асоціації телемедицини «предмет телемедицини полягає в передаванні медичної інформації між віддаленими один від одного пунктами, де знаходяться пацієнти, лікарі, інші провайдери медичної допомоги, між окремими медичними закладами». По суті, телемедицина - це надання медичної допомоги хворим за рахунок поєднання комп’ютерів, Інтернету та інших комунікаційних технологій з медичним досвідом [3].

Підкреслимо, що нормативно-правового регулювання для мобільної медицини поки не має. Ця нормативна невизначеність перешкоджає розвитку інноваційних мобільних пристроїв та медичних програм і сповільнює їх прийняття у практику охорони здоров'я. Лікарі досі побоюються використовувати мобільні пристрої через те, що ці медичні програми є ненадійними і не були перевірені.

\section{Висновки.}

1. Мобільні пристрої потребують пильної уваги, перш за все внаслідок високої їх ефективності в умовах обмежених ресурсів.

2. Для забезпечення ефективного впровадження технологій М-медицини потрібна прискорене розроблення нормативно-правового забезпечення застосування мобільних пристроїв. 


\section{Література.}

1. Е-медицина [Електронний ресурс]. - Режим доступу: https://uk.wikipedia.org/wiki/E-медицина.

2. Качмар В. О. Напрямки розвитку інформаційних технологій у медицині / В. О. Качмар, В. І. Авраменко // Медицина транспорту України. - 2011. - № 3. - С. 96-103. 3. Панченко О. А. Медицина и интернет / О. А. Панченко, Ю. Е. Лях, В. Г. Антонов. - [1-е изд., испр.]. - Донецк : СПД Дмитренко, 2008. - 524 с.

4. Проблеми чинної вітчизняної нормативно-правової бази у сфері боротьби із кіберзлочинністю: основні напрями реформування. Аналітична записка [Електронний ресурс] / офіційний сайт Національного інституту стратегічних досліджень. - Режим доступу: http://www. niss.gov.ua/articles/454.

5. Чібісова М. Хмарні технології-майбутнє медицини? / М. Чібісова // Ваше здоров’я. - 2013. - № 51-52. - С. 21. 6. Ahmed B. There will be more than 13,000 medical apps in 2012 in Apple Appstore [Electronic resource] / B. Ahmed // Medicalopedia medical news blog. - 23 Aug, 2011. - Retrieved from : http://medicalopedia.org/1509/13000medical-apps-2012-apple-appstore.

7. An observational study to assess an electronic point-of-care wound documentation and reporting system regarding user satisfaction and potential for improved care / B. Florczak, A. Scheurich, J. Croghan [et al.] // Ostomy Wound Manage. - 2012. - Vol. 58, No. 3. - P. 46-51.

8. Della Mea V. What is e-Health (2): the death of telemedicine? / V. Della Mea // J. Med. Internet Res. - 2001. - Vol. 3, No. 2. - P. e22.

9. Design and implementation of a smartphone-based portable ultrasound pulsed-wave doppler device for blood flow measurement / C. C. Huang, P. Y. Lee, P. Y. Chen, T. Y. Liu // IEEE Trans. Ultrason. Ferroelectr. Freq. Control. - 2012. - Vol. 59, No. 1. - P. 182-189.

10. Eysenbach G. The role of e-health and consumer health informatics for evidence-based patient choice in the 21st century / G. Eysenbach // Clin. Dermatol. - 2001. - Vol. 19, No. 1. - P. 11-17.

11. Garvin W. The legal perspective of mHealth in the United States / W. Garvin // Journal MTM. - 2012. - Vol. 1, No. 4. - P. 42-45.

12. How smartphones are changing the face of mobile and participatory healthcare: an overview / M. N. K. Boulos, S. Wheeler, C. Tavares, R. Jones // Biomed. Eng. Online. - 2011. - No. 10. - P. 24.

13. Implementing e-Health in developing countries: guidance and principles [Electronic resource] / International Telecommunication Union official site. - September 2008. - 53 p. - Retrieved from : https://www.itu.int/ITU-D/cyb/ app/docs/e-Health_prefinal_15092008.PDF.

14. Integrated rapid-diagnostictest reader platform on a cellphone / O. Mudanyali, S. Dimitrov, U. Sikora [et al.] // Lab. Chip. - 2012. - Vol. 12, No. 15. - P. 2678-2686. 15. Integration of cell phone imaging with microchip ELISA to detect ovarian cancer HE4 biomarker in urine at the point-of-care / S. Wang, X. Zhao, I. Khimji [et al.] // Lab. Chip. - 2011. - Vol. 11, No. 20. - P. 3411-3418.

16. Lensfree microscopy on a cellphone / D. Tseng, O. Mudanyali, C. Oztoprak [et al.] // Lab. Chip. - 2010. Vol. 10, No. 14. - P. 1787-1792.

17. Melanoma screening with cellular phones / C. Massone, R. Hofmann-Wellenhof, V. Ahlgrimm-Siess [et al.] // PLoS ONE. - 2007. - Vol. 2, No. 5. - P. 483.

18. Mobile medical applications: Guidance for Food and Drug Administration staff [Electronic resource] / U.S. Food and Drug Administration official site. - 44 p. - Retrieved from : http://www.fda.gov/downloads/Medical Devices/.../ UCM263366.pdf.

19. Mobile teledermatology for skin tumour screening: diagnostic accuracy of clinical and dermoscopic image teleevaluation using cellular phones / S. Kroemer, J. Fruhauf, T. M. Campbell [et al.] // Br. J. Dermatol. - 2011. - Vol. 164, No. 5. - P. 973-979.

20. Novel uses of smartphones in ophthalmology / R. K. Lord, V. A. Shah, A. N. San Filippo, R. Krishna // Ophthalmology. - 2010. - Vol. 117, No. 6. - P. 1274.

21. Oliveira B. S. 15 More smartphone apps to improve your practice [Electronic resource] / B. S. Oliveira // Medscape website. - 2012. - Retrieved from : www.medscape.com/ features/slideshow/apps2

22. Optofluidic fluorescent imaging cytometry on a cell phone / H. Zhu, S. Mavandadi, A. F. Coskun [et al.] // Anal. Chem.- 2011. - Vol. 83, No. 17. - P. 6641-6647.

23. Perera C. The evolution of e-Health - mobile technology and mHealth / C. Perera // Journal MTM. - 2012. - Vol. 1, No. 1. - P. 1-3.

24. Rapid wireless transmission of head CT images to a personal digital assistant for remote consultation / V. Yaghmai, S. A. Salehi, S. Kuppuswami, J. W. Berlin // Acad. Radiol. - 2004. - Vol. 11, No. 11. - P. 1291-1293.

25. Remote real-time monitoring of free flaps via smartphone photography and $3 g$ wireless internet: a prospective study evidencing diagnostic accuracy / H. Engel, J. J. Huang, C. K. Tsao [et al.] // Microsurgery. - 2011. - Vol. 31, No. 8. - P. 589-595.

26. Šindelář O. Image deblurring in smartphone devices using built-in inertial measurement sensors / O. Šindelář, F. Šroubek // J. Electron. Imaging. - 2013. - Vol. 22, N. 1. - P. 1-22.

27. Smartphone-assisted guide for the placement of ventricular catheters / U. W. Thomale, T. Knitter, A. Schaumann [et al.] // Childs Nerv. Syst. - 2013. - Vol. 29, No. 1. - P. 131-139.

28. Smartphone use and acceptability among clinical medical students: a questionnaire-based study / T. Robinson, T. Cronin, H. Ibrahim [et al.] // J. Med. Syst. - 2013. Vol. 37, N. 3. - P. 9936.

29. Tahat A. A. Mobile personal electrocardiogram monitoring system and transmission using MMS / A. A. Tahat // Proceedings of the 7th International Caribbean 
Conference on Devices, Circuits and Systems (ICCDCS '08), 28-30 April 2008, Cancún, Mexico. - 2008. - P. 1-5. 30. Teleconsultation with the mobile camera-phone in digital soft-tissue injury: a feasibility study / C. H. Hsieh, H. H. Tsai, J. W. Yin [et al.] // Plast. Reconstr. Surg. - 2004. - Vol. 114, No. 7. - P. 1776-1782.

31. The effectiveness of mobile-health technologies to improve health care service delivery processes: a systematic review and meta-analysis / C. Free, G. Phillips, L. Watson [et al.] // PLoS Med. - 2013. - Vol. 10, No. 1. - P. e1001363.

\section{References.}

1. E-meditsina [E-medicine]. (2016, May 29). Retrieved from https://uk.wikipedia.org/wiki/E-meditsina [In Russian].

2. Kachmar, V. O., Avramenko, V. I. (2011). Napryamki rozvitku informatsiinikh tekhnologii u meditsini. [The trends of the informational technologies' development in medicine]. Meditsina Transportu Ukraini (Medicine of Ukrainian Transport), 3, 96-103 [In Ukrainian].

3. Panchenko, O. A., Lyakh, Yu. E., Antonov, V. G. (2008). Meditsina i internet. [Medicine and Internet]. (1st ed.). Donetsk: SPD Dmitrenko [In Russian].

4. Problemi chinnoi vitchiznyanoi normativno-pravovoi bazi u sferi borotbi iz kiberzlochinnistyu: osnovni napryami reformuvannya [Problems of existing domestic legal and regulatory framework in the fight against cyber crime: the main directions of reform]. Analytic note. (n.d.). Retrieved from the National Institute for Strategic Studies website, http://www.niss.gov.ua/articles/454 [In Ukrainian].

5. Chibisova, M. (2013). Khmarni tekhnologii - maibutnie meditsini? [Cloud technology is the future of medicine?] Vashe Zdorovya, 51-52, 21 [In Ukrainian].

6. Ahmed, B. (2011, August 23). There will be more than 13,000 medical apps in 2012 in Apple Appstore. [Medicalopedia medical news blog post]. Retrieved from http://medicalopedia.org/1509/13000-medical-apps-2012apple-appstore.

7. Florczak, B., Scheurich, A., Croghan, J., Sheridan, P. Jr, Kurtz, D., McGill, W., McClain, B. (2012). An observational study to assess an electronic point-of-care wound documentation and reporting system regarding user satisfaction and potential for improved care. Ostomy Wound Manage, 58(3), 46-51.

8. Della Mea, V. (2001) What is e-Health (2): the death of telemedicine? J. Med. Internet Res., 3(2), e22. doi: 10.2196/ jmir.3.2.e22

9. Huang, C. C., Lee, P. Y., Chen, P. Y., Liu, T. Y. (2012). Design and implementation of a smartphone-based portable ultrasound pulsed-wave doppler device for blood flow measurement. IEEE Trans. Ultrason. Ferroelectr. Freq. Control., 59(1), 182-189. doi: 10.1109/TUFFC.2012.2171.
32. Validation of Near Eye Tool for Refractive Assessment (NETRA) - pilot study / A. Bastawrous, C. Leak, F. Howard, V. Kumar // J. MTM. - 2012. - Vol. 1, No. 3. - P. 6-16. 33. 500m people will be using healthcare mobile applications in 2015 [Electronic resource] / Research 2 Guidance official site. - Nov 2010 - Retrieved from : http://research2guidance. com/2010/11/

10/500m-people-will-be-using-healthcare-mobileapplications-in-2015-2.

10. Eysenbach, G. (2001). The role of e-health and consumer health informatics for evidence-based patient choice in the 21st century. Clin. Dermatol., 19(1), 11-17. doi: 10.1016/ S0738-081X(00)00202-9

11. Garvin, W. (2012). The legal perspective of mHealth in the United States. Journal MTM, 1(4), 42-45. doi:10.7309/ jmtm.82

12. Boulos, M. N. K., Wheeler, S., Tavares, C., Jones, R. (2011). How smartphones are changing the face of mobile and participatory healthcare: an overview. Biomed. Eng. Online, 10, 24. doi: 10.1186/1475-925X-10-24.

13. Implementing e-Health in developing countries: guidance and principles. (2008, September). Retrieved from International Telecommunication Union website: https://www.itu.int/ITU-D/cyb/app/docs/e-Health_ prefinal_15092008.PDF.

14. Mudanyali, O., Dimitrov, S., Sikora, U., Padmanabhan, S., Navruz, I., Ozcan, A. (2012). Integrated rapiddiagnostictest reader platform on a cellphone. Lab. Chip., 12(15), 2678-2686. doi: 10.1039/c2lc40235a

15. Wang, S., Zhao, X., Khimji, I., Akbas, R., Qiu, W., Edwards, D., ... Demirci, U. (2011). Integration of cell phone imaging with microchip ELISA to detect ovarian cancer HE4 biomarker in urine at the point-of-care. Lab. Chip., 11(20), 3411-3418. doi: 10.1039/c1lc20479c

16. Tseng, D., Mudanyali, O., Oztoprak, C., Isikman, S. O., Sencan, I., Yaglidere, O., Ozcan, A. (2010). Lensfree microscopy on a cellphone. Lab. Chip., 10(14), 1787-1792. doi: 10.1039/c003477k

17. Massone, C., Hofmann-Wellenhof, R., Ahlgrimm-Siess, V. Gabler, G., Ebner, C., Soyer, H. P. (2007). Melanoma screening with cellular phones. PLoS ONE, 2(5), 483. doi: 10.1371/journal.pone.0000483

18. Mobile medical applications: Guidance for Food and Drug Administration staff. (2013, September 25). Retrieved from U.S. Food and Drug Administration website: http://www.fda.gov/downloads/Medical Devices/.../ UCM263366.pdf.

19. Kroemer, S., Fruhauf, J., Campbell, T. M., Massone, C., Schwantzer, G., Soyer, H. P., Hofmann-Wellenhof, R. (2011). Mobile teledermatology for skin tumour screening: 
diagnostic accuracy of clinical and dermoscopic image teleevaluation using cellular phones. Br. J. Dermatol., 164(5), 973-979. doi: 10.1111/j.1365-2133.2011.10208.x. 20. Lord, R. K., Shah, V. A., San Filippo, A. N., Krishna, R. (2010). Novel uses of smartphones in ophthalmology. Ophthalmology, 117(6), 1274. doi: 10.1016/j. ophtha.2010.01.001.

21. Oliveira, B. S. (2012). 15 More smartphone apps to improve your practice. Retrieved from Medscape website: www.medscape.com/features/slideshow/apps2.

22. Zhu. H., Mavandadi, S., Coskun, A. F., Yaglidere, O., Ozcan, A. (2011). Optofluidic fluorescent imaging cytometry on a cell phone. Anal. Chem., 83(17), 6641-6647. doi: 10.1021/ac201587a.

23. Perera, C. (2012). The evolution of e-Health - mobile technology and mHealth, Journal MTM, 1(1), 1-3. doi:10.7309/jmtm.1

24. Yaghmai, V., Salehi, S. A., Kuppuswami, S., Berlin, J. W. (2004). Rapid wireless transmission of head CT images to a personal digital assistant for remote consultation. Acad. Radiol., 11(11), 1291-1293. doi: 10.1016/j.acra.2004.07.020 25. Engel, H., Huang, J. J., Tsao, C. K., Lin, C. Y., Chou, P. Y., Brey, E. M., ... Cheng, M. H. (2011). Remote realtime monitoring of free flaps via smartphone photography and $3 g$ wireless internet: a prospective study evidencing diagnostic accuracy. Microsurgery, 31(8), 589-595. doi: 10.1002/micr.20921

26. Šindelár̆, O., Šroubek, F. (2013). Image deblurring in smartphone devices using built-in inertial measurement sensors. J. Electron. Imaging, 22(1). 1-22. doi:10.1117/1. JEI.22.1.011003

27. Thomale, U. W., Knitter, T., Schaumann, A., Ahmadi, S. A., Ziegler, P., Schulz, M., Miethke, C. (2013). Smartphone-assisted guide for the placement of ventricular catheters. Childs Nerv. Syst., 29(1), 131-139. doi: 10.1007/ s00381-012-1943-1

28. Robinson, T., Cronin, T., Ibrahim, H., Jinks, M., Molitor, T., Newman, J., Shapiro, J. (2013). Smartphone use and acceptability among clinical medical students: a questionnaire-based study. J. Med. Syst., 37(3), 9936. doi: 10.1007/s10916-013-9936-5

29. Tahat, A. A. (2008, April 28-30). Mobile personal electrocardiogram monitoring system and transmission using MMS. Proceedings of the 7th International Caribbean Conference on Devices, Circuits and Systems (ICCDCS '08), Cancún, Mexico, 1-5. doi: 10.1109/ICCDCS.2008.4542630 30. Hsieh, C. H., Tsai, H. H., Yin, J. W., Chen, C. Y., Yang, J. C., Jeng, S. F. (2004). Teleconsultation with the mobile camera-phone in digital soft-tissue injury: a feasibility study. Plast. Reconstr. Surg., 114(7), 1776-1782.

31. Free, C., Phillips, G., Watson, L., Galli. L., Felix, L., Edwards, P., ... Haines, A. (2013). The effectiveness of mobile-health technologies to improve health care service delivery processes: a systematic review and meta-analysis. PLoS Med., 10(1), e1001363. doi: 10.1371/journal. pmed.1001363

32. Bastawrous A., Leak, C., Howard, F., Kumar, V. (2012). Validation of Near Eye Tool for Refractive Assessment (NETRA) - pilot study. J. MTM, 1(3), 6-16. doi:10.7309/ jmtm.17

33. 500m people will be using healthcare mobile applications in 2015. (2010, November). Retrieved from Research 2 Guidance website:

http://research2guidance.com/2010/11/

10/500m-people-will-be-using-healthcare-mobileapplications-in-2015-2. 